\title{
Research on Institutional Construction of College Students Ideological and Political
}

\section{Education}

\author{
Dong-xia $\mathrm{Wu}$ \\ The Academic Affairs Office_ \\ Xuanhua Science\& Technology Vocational College \\ Xuanhua, China
}

\begin{abstract}
College students are the backbone of socialist construction, ideological and political education of college students is the key to the socialist modernization services. This paper starts from the present situation of ideological and political education of college students, then analysis the problems of the current ideological and political education building and proposes feasible measures to the ideological education systematic construction.
\end{abstract}

Keywords: institutional construction; ideological and political; college student

\section{INTRODUCTION}

College students are a valuable resource for the community, which is the new force of China's socialist construction features and future successors of the socialist construction. Higher education includes many aspects, including education of professional knowledge psychological education and ideological and political education of professional knowledge. Among them, the ideological and political education in higher education is the most important. The outcomes of the ideological and political education determine whether the students could meet the requirements of society builders and affect the process of China's socialist construction. Meanwhile, with the continuous development of social modernization, more and more new trend and new culture have a significant impact on student education colleges and universities, so the ideological and political education is even more important and urgent. However, there are still many shortcomings in the ideological and political education. References [1] pointed out some problems existing in the construction of ideological and political education, for example, local government departments and universities do not pay enough attention to ideological and political education and have little methods, ideological and political education theory courses have not been fully expanded, textbooks lag and are not combined with practical ${ }^{[1]}$. Xu pointed out the important role of ideological and political education in the education of college students, which will directly affect the socialization process. It shows the importance of ideological and political education in higher education ${ }^{[2]}$.
The main reason why the current problems exist is that we do not establish a sound system of ideological and political education. A system is an indemnification, and an imperfect system can result in a series of ideological education problems. Zhang Wenxue proposed an idea that the level of institutional construction has a direct impact on the expansion and effect of the construction of ideological and political of college students in his $\mathrm{PhD}$ thesis ${ }^{[3]}$. Whether the construction of ideological and political education could be successful is depended on whether we can establish a sound system to ensure the implementation of the ideological and political education from the system.

This paper starts from the present situation of ideological and political education of college students, then analysis the problems of the current ideological and political education building and proposes feasible measures to the ideological education systematic construction.

\section{Current status of the construction of ideological and political education of college students}

The education of ideological and political determines the moral of college students and decides the students whether meet the requirements of socialist builders and successors. Currently, the construction of ideological and political education of college students has made some achievements, but there are still many problems. After practice investigation, there are several aspects of its main problems as following:

(1)Universities leaders failed to establish a correct concept of ideological and political education

Universities have their own management programs and the difference of different colleges and universities is obvious. Nowadays, many colleges and universities emphasize the importance of ideological and political education only in theory but in practice they rarely do. Most colleges and universities only emphasizes the education of expertise and the employment rate of students to establish a good brand to attract more students and the social resources in the community, while ignoring the importance of construction of ideological and political education of colleges students. As we all know, only the ability and political integrity of college students is in line with Chinese socialist builders and successors. 
(2)The division of responsibility of ideological and political education is not clear

In the system, the role of the leading group of universities is overall planning and the implementation of the mandate needs to be sent to each college, each department and then specific to each member of the class. And it's difficult to form a common cooperation because the task is not clear due to gradually transfer between stages, which will result in the implementation of the policy can't be true and can't be expected to achieve the desired effect. Therefore, we must strengthen the relationship between different departments when assign tasks ${ }^{[4]}$.

(3) Lack of ideological and political education construction workforce

Ideological and political education is not on paper, but rather a combination of theory and practice, which is a protracted war and needs a dedicated team of Ideological Education. However, most universities are short of a team like this. With the expansion of the scale of the higher education, the former ideological and political education workforce is unable to meet the current needs and its own ideological and political consciousness also can't meet the currents and the quality of the team needs to be further improved. Most members of the team can't play a good role in promoting the education of ideological and political of college students due to the too old thoughts that cannot keep up with the times and they do not focus on their own development and so on.

(4)Lack of institutional safeguards

Ideological and political education is a huge systematic project. Most colleges and universities are short of effective, standardized and workable institutional support, leading to the objectives and requirements of ideological and political education are not possible to implement the management staff at all levels. There are also many serious problems in the implementation of the system. Some colleges and universities have specific rules and regulations but they ignore them in the actual construction of ideological and political process, so the rules and regulations have just become nothing ${ }^{[5]}$.

(5)Lack of material security

The expansion of any school work will inevitably require financial security, which will increase the cost of running the school. Overall speaking, the expenditure ratio of ideological and political education is minimal, which result in a lack of financial security and physical security and the construction of ideological and political education cannot be expanded properly.

The basic reason why these problems exist is that the colleges and universities do not institutionalize the construction of ideological and political and implement them ${ }^{[6]}$. Therefore, the most importance thing we must to do is that establish a sound system of ideological and political education and to ensure the implementation institutionally.

\section{The main problems exists in the institutional building}

There are some problems in development, implementation and evaluation in the construction of ideological and political education as followings ${ }^{[7]}$.

\subsection{Development of the system is not perfect}

Developing a sound system is the basis and prerequisite. Developing a system of ideological and political education is based on the national development of the system files on the ideological and political content and national law and the actual needs. Sound a system or not, directly binding normative role of the system, which will creates the possible failure for the construction of ideological and political education. An unsound system mainly includes incomplete content, blind development and do not consider the social and moral issues.

\subsection{Lack of executive power}

Development of the system is to be executed. If the system has been developed but do not perform, then the system will become a dead letter. Only through the specific implementation, can we detection the effectiveness and possible limitations in practice. Most colleges and universities have developed a lot of systems on ideological and political education, but the results are not so good. The main reason is that the implementations are short of executive power. During the execution of the ideological and political education system, there is a serious phenomenon that they just go about the process and as a consequence, the system does not play its real role in the education of ideological and political.

\subsection{Lack of effectiveness}

Effectiveness refers to the impact of the implementation of ideological and political education to college students, including positive and negative. In recent years, although there are some securities on the implementation of the ideological and political education, but the result is unsatisfactory. The mainly reason is that the enthusiasm of students are not high and the duration of the ideological and political education is too short. Students' participation is not high mainly due to students do not have an accurate understanding of the ideological and political education and do not realize the importance of the ideological and political education, even more, some of them have a resistant emotional to it.

\section{Strengthen the institutional construction of ideological and political education of college students}

College students' ideological and political education is a very important part of higher education. Establish a sound system is a system guarantee to the ideological and political education. This paper analysis the problems existing in the 
institutional building and then propose some ideas to strengthen the ideological and political education.

\subsection{Improve the understanding of the importance of the ideological and political education}

There are some resistances in the expansion of ideological and political is because the leaders, school staff, students do not recognize the extent of the ideological and political education well and do not understand the importance of ideological and political education in higher education. Universities Leadership is leadership school policy makers, if the leaders of universities are unable to pay attention to ideological and political education from the concept, the ideological and political education will not be able to expand, higher education colleges and universities will also be a failure. University administrators have to strengthen their understanding of the ideological and political education and improve their ideological and political consciousness, then develop a sound ideological and political education system and to guarantee the correct implementation of the ideological and political education fundamentally. Students' level of awareness of the ideological and political education is not high mainly because of the bad implementation of ideological and political education in colleges and universities, which is not introduced into daily learning among education. Therefore, in addition to develop a sound ideological and political education system, the leaders need to find ways to introduce the ideological and political education into daily life, only in the form of monasteries, can the college students form a concept of ideological and political education $^{[8]}$.

\subsection{Establish a feedback mechanism}

Campus is a complete small community, and exchange material and information with the social environment all the time. College students are also exposed to the social environment and their values will vary with changes in society, leading to the ideological and political education have to change with. Therefore, we must build a sound feedback mechanism of the construction of the ideological and political education.

\subsection{Establish a complete monitoring mechanism}

The implementation of the system developed by university administrators need division of labor and cooperation at all levels departments to be complete. If there is no clear monitoring mechanism, every department will become random and rambling, so it is of great necessary to establish a complete monitoring mechanism. At the same time, we have to establish a public evaluation and multi-channel monitoring mechanism. Only establishing a comprehensive monitoring mechanism, will the expansion of ideological and political education performs well.

\section{Conclusions}

Ideological and political education in higher education building is a very important part, which determines whether the education of the students qualify as the requirements of socialism with Chinese characteristics builders and successors. Only by strengthening the institutional construction, can ideological and political education be truly effective. University administrators should improve the ideological and political education system all the time in an innovative thinking and a wide perspective to achieve continuous development and innovation of ideological and political education.

\section{Reference}

[1] CPC Central Committee and State Council on further strengthening and improving ideological and political education [N], People's Daily, 2004-10-15.

[2] Xu.Jiangchao, "Research on Institutionalization of Ideological and Political Education for College Students ", Innovation Education, 103.

[3] Zhang.Wenxue, "Research on Institutionalization of Ideological and Political Education for College Students", China University of Geosciences, pp.12-13, 2012.

[4] Chen.Yuling, "Research on Institutionalization of Ideological and Political for College Students ", Vocational education, pp.292-294.

[5] Duan.Bo, "Research on Institutionalization of Ideological and Political Education for College Students", Journal of Yan'an Vocational \& Technical Institute, pp.41-43, 2014.

[6] Xu.Junbao, "Route studies about the realization that college student ideological and political education science", Zhengzhou University, pp.43-50, 2013.

[7] Wang.Yuhan, "Construction of college students' ideological and political education lasting mechanism", Liaoning Normal University, pp.12-16, 2012.

[8] Lei.Suibin, "Research on the Staff Construction of College Student's Ideological and political Education in the new Era", Southwest University, pp.21-28, 2008. 